\title{
The effect of trajectory of serum uric acid on patients and renal outcomes in patients with stage- 3 chronic kidney disease
}

Shangfeng Tsai(Former Corresponding Author)

National Taichung University of Science and Technology

Cheng-Hsu Chen

Taichung Veterans General Hospital

Ming-Ju Wu

Taichung Veterans General Hospital

Chia-Lin Lee(New Corresponding Author) ( $\nabla$ ymdoctor@hotmail.com )

https://orcid.org/0000-0002-4705-9419

Research article

Keywords: uric acid, patient survival, renal survival, long-term effect, trajectory, competing risk analysis

Posted Date: May 4th, 2020

DOI: https://doi.org/10.21203/rs.2.15346/v3

License: (c) (i) This work is licensed under a Creative Commons Attribution 4.0 International License.

Read Full License 
The authors have withdrawn this preprint from Research Square 